\title{
NopB, a Soybean Cultivar-Specificity Protein from Sinorhizobium fredii USDA257, Is a Type III Secreted Protein
}

\author{
Julio C. Lorio, ${ }^{1}$ Won Seok Kim, ${ }^{2}$ and Hari B. Krishnan ${ }^{2,3}$ \\ ${ }^{1}$ Plant Microbiology and Pathology, ${ }^{2}$ Department of Agronomy, and ${ }^{3}$ United States Department of Agriculture-Agricultural \\ Research Service, Plant Genetics Research Unit, University of Missouri, Columbia, MO 65211, U.S.A.
}

Submitted 12 April 2004. Accepted 4 July 2004.

The type III secretion system (TTSS) of plant- and animalpathogenic bacteria is involved in translocation of virulence factors into the host cell cytosol where they modulate cellular processes. Sinorhizobium fredii USDA257 is a gram-negative soil bacterium that forms nitrogen-fixing nodules on specific soybean cultivars (Glycine max (L.) Merr.). This microsymbiont is known to secrete at least five nodulation outer proteins (Nops) in response to flavonoid induction. Some of these Nops have been shown to be secreted by TTSS in this symbiotic bacterium. We have isolated and purified an 18-kDa extracellular protein from flavonoid-induced cultures of USDA257. The N-terminal amino acid sequence of this purified protein was identical to the published sequence of the soybean cultivar-specificity protein, NopB (formerly NolB). Inactivation of $r h c N$, which encodes an ATPase, abolished secretion of NopB. Similarly, a nonpolar nopB deletion mutant was compromised in its ability to secrete several Nops. A construct containing the coding region of $n o p B$ under control of a T7 promoter was expressed successfully in Escherichia coli and, subsequently, the recombinant NopB was purified by nickel-affinity column chromatography. Polyclonal antibodies raised against purified recombinant NopB were used in Western blot analysis to demonstrate the association of NopB with pilus-like surface appendages. Deletion analysis indicated that the first $33 \mathrm{~N}$-terminal residues of NopB were necessary and sufficient to mediate the secretion of a green fluorescent protein reporter. Introduction of plasmid-borne extra copies of nopB into USDA257 resulted in lower accumulation of native NopB. We also show that USDA257 and its nonpolar nopB deletion mutant exhibited discernible differences in their ability to nodulate legume hosts.

Although Sinorhizobium fredii USDA257 (hereafter referred as USDA257) has a broad range of hosts (Pueppke and Broughton 1999), this bacterium engages in nitrogen-fixing symbiosis only with primitive soybean cultivars (Keyser et al. 1982). It does not form functional nodules on agronomically improved cultivars such as McCall (Heron and Pueppke 1984; Meinhardt et al. 1993). The inability of USDA257 to form func-

Corresponding author: H. B. Krishnan; Telephone: 573-882-8151; Fax: 573-884-7850; E-mail: KrishnanH@ missouri.edu

This article is in the public domain and not copyrightable. It may be freely reprinted with customary crediting of the source. The American Phytopathological Society, 2004. tional nodules on commercially improved cultivars is controlled by a cluster of six open-reading frames (ORFs), designated nol XWBTUV, (Kovacs et al. 1995; Meinhardt et al. 1993), which is located on a symbiosis (sym) plasmid (Heron et al. 1989; Meinhardt et al. 1993). A mutation in any of these ORFs enables USDA257 to nodulate cv. McCall. Mutations in the nolXWBTUV locus also confer an additional phenotype termed competitive nodulation blocking (Balatti and Pueppke 1990). If cells of USDA257 are present in the inoculum, the mutant's ability to nodulate McCall soybean is severely attenuated. It has been proposed that a cultivar-specificity region is involved in the synthesis of effector molecules that abrogate functional nodulation on McCall (Balatti and Pueppke 1990).

Sequence of the nolXWBTUV locus and adjacent regions of the sym plasmid in USDA257 is homologous to components of the type III secretion system (TTSS) in pathogenic bacteria (Kovacs et al. 1995; Meinhardt et al. 1993). The genetic organization and complete nucleotide sequence of the TTSS of USDA257 recently was reported (Krishnan et al. 2003) and found to be very similar to that of Rhizobium sp. NGR234. On the basis of sequence similarity with TTSS genes of other plant symbionts, some of the soybean cultivar specificity genes located on sym plasmid were renamed rhc (rhizobia conserved) (Göttfert et al. 2001; Krishnan et al. 2003; Viprey et al. 1998). For example, nolT was named rhcJ, and nolW was named $r h c C 1$. In pathogenic bacteria, the TTSS consists of a cluster of genes coding for structural components of the secretion apparatus and putative effector proteins destined for secretion (Galan and Collmer 1999; He 1998; Lee 1997). These effector proteins do not contain a cleavable signal peptide and translocation may require both chaperone proteins and intimate bacteria-host contact (He 1998). The structural components of TTSS are highly conserved among bacterial pathogens and function to deliver effector proteins into host cells (Galan and Collmer 1999; He 1998; Lee 1997; Marie et al. 2001).

Extracellular proteins have been implicated in regulating legume nodulation. For example, NodO of Rhizobium leguminosarum bv. viciae has been shown to play a role in extending the host range of this strain (Economou et al. 1994; Sutton et al. 1994). A calcium-binding protein, calsymin of $R$. etli, has been implicated in bacteroid development and nitrogen fixation (Xi et al. 2000). Earlier, we have demonstrated that USDA257 secretes proteins called nodulation outer proteins (Nops) into the environment upon flavonoid induction (Krishnan and Pueppke 1993; Krishnan et al. 1995, 2003). Secretion of Nops is regulated by both nodD1 and $\operatorname{nodD2}$, and is dependent on the soybean cultivar-specificity locus (Krishnan et al. 
1995). One of the Nops secreted by USDA257 has been identified as NopX (formerly NolX), a type III effector protein involved in regulating soybean cultivar-specific nodulation (Krishnan 2002). Recent studies have shown that NopL (formerly $y 4 x L$ ) from NGR234 is a type III effector protein. NopL was shown to undergo phosphorylation in vitro and perturb the host signal transduction pathway (Bartsev et al. 2003, 2004). To fully understand the role of Nops in regulating nodulation on legumes, it is imperative that the identity and functions of these proteins be determined. In this study, we have identified an 18-kDa TTSS-secreted protein as NopB (formerly NolB) and provide biochemical evidence for the association of this protein with pili-like surface appendages. In addition, we demonstrate that the first $33 \mathrm{~N}$-terminal amino acids of NopB were necessary and sufficient for the secretion of a fused reporter protein to the media.

\section{RESULTS}

\section{Type III secretion system of $S$. fredii USDA257.}

TTSSs have been identified in several symbiotic bacteria, including $S$. fredii USDA257, Rhizobium sp. strain NGR234, R. etli CFN42, Mesorhizobium loti MAF303099, and Bradyrhizobium japonicum USDA110 (Marie et al. 2001). The genetic organization of TTSS loci of USDA257 (Fig. 1) and NGR234 (Viprey et al. 1998) are remarkably similar. A cluster of genes (nolXWBTUV) located in TTSS locus of USDA257 has been identified earlier to be involved in regulating soybean cultivar specificity (Meinhardt et al. 1993). These genes also are present in NGR234 and other rhizobia but have been assigned different names, resulting in confusing nomenclature. To minimize this confusion, a standard nomenclature for the genes present in the TTSS has been proposed (Marie et al. 2001; Viprey et al. 1998). The current nomenclature of the genes located in the TTSS of USDA257 and NGR234 is provided in Table 1.

\section{Identification of an 18-kDa flavonoid-induced extracellular protein as NopB.}

In response to flavonoid induction, USDA257 secretes at least five Nops ranging in molecular weight from 7 to $64 \mathrm{kDa}$ (Krishnan and Pueppke 1993; Krishnan et al. 2003). We have established that the $64-\mathrm{kDa}$ flavonoid-induced extracellular protein is NopX (Krishnan 2002). The 7-kDa protein, which is the most abundant protein in the extracellular media of flavonoid-induced cultures, has been identified as NopA (Marie et al. 2003). In NGR234, a 37-kDa Nop has been identified as NopL and has been shown to be involved in suppressing plant defense response (Bartsev et al. 2004). NopL also is present in USDA257, but has not yet been characterized. In addition, the identity of several flavonoid-induced extracellular proteins remains to be elucidated. In order to identify these Nops, we obtained extracellular proteins from flavonoid-induced USDA257 cultures and resolved them by preparative gel electrophoresis. An $18-\mathrm{kDa}$ protein was purified from the preparative gel and was subjected to $\mathrm{N}$-terminal amino acid sequencing. The N-terminal amino acid sequence, MMLPVTSISNSLPRVASS, was subjected to BLAST search (National Center for Biotechnology Information) and found to be identical to that published for NopB (Meinhardt et al. 1993). Search of protein databases also revealed the presence of NopB in TTSS-containing symbiotic bacteria, including $S$. fredii HH103, NGR234, $M$. loti MAFF303099, and B. japonicum 110spc4. The NopB of $S$. fredii HH103 (Swiss-Prot database accession number AAK60403) and USDA257 are identical. The NopB of USDA257 and NGR234 is composed of 164 amino acids and is $98 \%$ homologous. The NopB of $M$. loti and B. japonicum consist of 167 and 170 amino acids and shows 63 and $44 \%$ identity, respectively, with that of USDA257 NopB (Fig. 2).

\section{Expression of NopB in Escherichia coli.}

To characterize NopB, the coding region of the gene under control of T7 promoter was introduced into Escherichia coli. This process resulted in the introduction of six histidine residues to the C-terminus region. When bacterial cells transformed with the plasmid were grown in the presence of isopropyl- $\beta$-Dthiogalactoside (IPTG), an $18-\mathrm{kDa}$ protein was produced, but was absent in noninduced cultures (Fig. 3). NopB began to accumulate in the bacterium within $1 \mathrm{~h}$ after induction. Accumulation of the recombinant NopB appears detrimental to E. coli because growth was arrested $1 \mathrm{~h}$ after the addition of IPTG. Recombinant NopB was purified by affinity chromatography and preparative gel electrophoresis. The gel-purified NopB, when resolved by sodium dodecyl sulfate-polyacrylamide gel electrophoresis (SDS-PAGE), revealed a single $18-\mathrm{kDa}$ protein with no contaminating polypeptides. Antiserum raised against recombinant NopB was used in a Western blot analysis of total proteins from induced and noninduced cultures. The polyclonal antibody showed strong reaction against the $18-\mathrm{kDa}$ protein (Fig. 3).

\section{Secretion of NopB is regulated by TTSS.}

Separation of extracellular proteins of $S$. fredii USDA257 by SDS-PAGE indicated that the $18-\mathrm{kDa}$ NopB was present only in flavonoid-induced, wild-type cultures (Fig. 4). A nonpolar nopB mutant, USDA257 1 nopB, was unable to secrete several of the Nops, including NopX, NopB, and NopA (Fig.
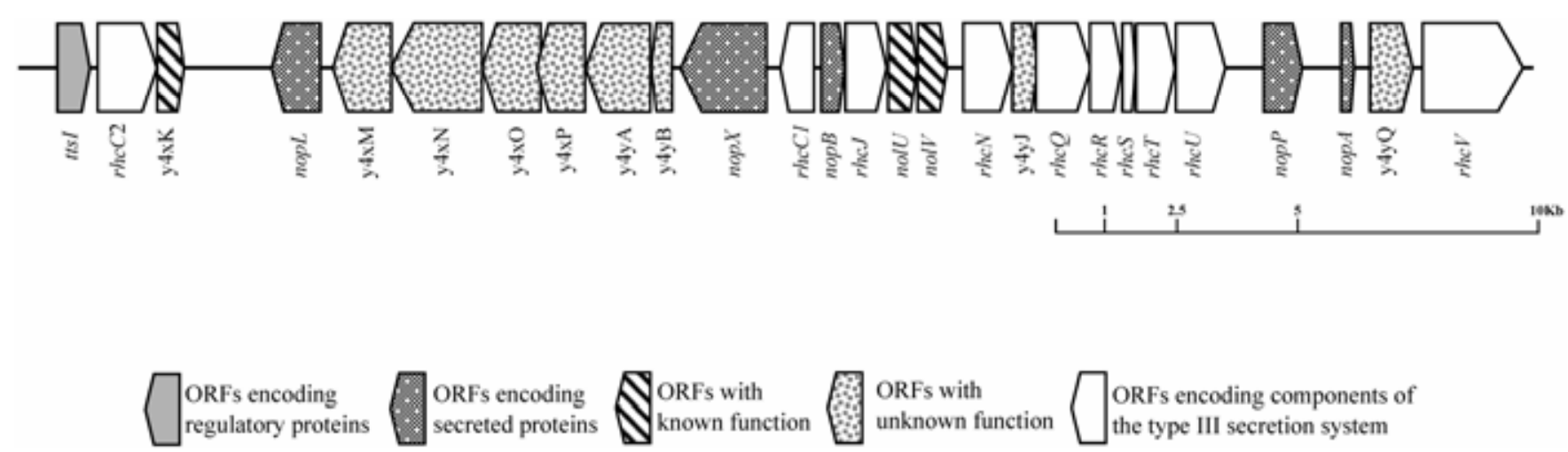

Fig. 1. Genetic organization of the type III secretion system (TTSS) locus of Sinorhizobium fredii USDA257. Genes located in the TTSS region and predicted open reading frames (ORFs) are indicated by arrow-shaped boxes. The TTSS of USDA257 and Rhizobium sp. strain NGR234 are almost identical; therefore, we have employed the same nomenclature for the genes and proteins used for NGR234. 
4). To determine if secretion of NopB was mediated by TTSS, we isolated the extracellular proteins from induced and noninduced cultures of an $r h c N$ mutant and resolved them by SDS-PAGE (Fig. 4A). The $r h c N$ gene encodes an ATPase and is necessary to energize the TTSS machinery

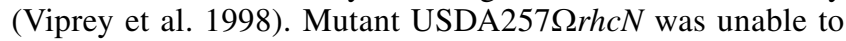
secrete several of the Nops, including NopB (Fig. 4A). This observation was further confirmed by Western blot analysis (Fig. 4B). The polyclonal antibody detected the presence of NopB in the extracellular protein preparation from the flavonoid-induced, wild-type cultures (Fig. 4B). The antibody failed to detect NopB in the flavonoid-induced cultures of the nonpolar nopB deletion mutant and $r h c N$ mutant of USDA257 (Fig. 4B).
First 33 N-terminal amino acids of NopB are sufficient for secretion.

To localize the sequences necessary for type III secretion of NopB, we incrementally deleted nucleotides from the 3 ' terminus of the coding region and created a translational fusion with a green fluorescent protein (GFP) reporter (Fig. 5). The nopB$g f p$ hybrid constructs were mobilized into USDA257 and secretion of the extracellular chimeric protein was determined by SDS-PAGE and immunoblotting. USDA257 carrying plasmids pHKB497, pHKB396, pHKB297, pHKB196, or pHKB99, which carried approximately $100 \mathrm{bp}$ deleted progressively from the C-terminus of the $\operatorname{nop} B$, were able to secrete the hybrid proteins into the medium (Fig. 6). Immunoblot analysis using NopB-specific antibodies detected secreted hybrid pro-

Table 1. Genes and open reading frames (ORFs) located in the type III secretion system (TTSS) of Sinorhizobium fredii USDA257 and Rhizobium sp. strain NGR234

\begin{tabular}{|c|c|c|c|c|c|}
\hline ORFs & $\begin{array}{c}\text { New } \\
\text { name }\end{array}$ & $\begin{array}{c}\text { Original } \\
\text { name }\end{array}$ & Codes for & Function/effect & References $^{\text {b }}$ \\
\hline $\mathrm{y} 4 \mathrm{xI}$ & $t t s I$ & $\ldots$ & TtsI & Transcriptional activator & Krishnan; Marie \\
\hline $\mathrm{y} 4 \mathrm{xJ}$ & $\operatorname{rhc} C 2$ & nolW & RhcC2 & Protein secretion/nodulation ${ }^{\mathrm{c}}$ & Krishnan; Marie \\
\hline $\mathrm{y} 4 \mathrm{xK}$ & $\operatorname{rhc} Q$ & $\ldots$ & RhcQ & Protein secretion/nodulation $^{c}$ & Viprey \\
\hline$y 4 x L$ & nopL & $\ldots$ & NopL & Secreted protein & Bartsev; Marie \\
\hline $\mathrm{y} 4 \mathrm{xM}$ & $\ldots$ & $\ldots$ & $\ldots$ & Unknown & Viprey; Krishnan \\
\hline $\mathrm{y} 4 \mathrm{xN}$ & $\ldots$ & $\ldots$ & $\ldots$ & Unknown & Viprey; Krishnan \\
\hline $\mathrm{y} 4 \mathrm{xO}$ & $\ldots$ & $\ldots$ & $\ldots$ & Unknown & Viprey; Krishnan \\
\hline $\mathrm{y} 4 \mathrm{xP}$ & $\ldots$ & $\ldots$ & $\ldots$ & Unknown & Viprey; Krishnan \\
\hline y4yA & $\ldots$ & $\ldots$ & $\ldots$ & Unknown & Jiang; Viprey \\
\hline y4yB & $\ldots$ & $\ldots$ & $\ldots$ & Unknown & Jiang; Viprey \\
\hline $\mathrm{y} 4 \mathrm{yC}$ & nopX & nolX & NopX (NolX, SR1) ${ }^{\mathrm{d}}$ & Secreted protein/cultivar-specific nodulation ${ }^{c}$ & Krishnan 93; Meinhardt; Krishnan 02 \\
\hline $\mathrm{y} 4 \mathrm{yD}$ & $\operatorname{rhcCl} 1$ & nolW & RhcC1 & Protein secretion/nodulation ${ }^{\mathrm{c}}$ & Meinhardt; Krishnan \\
\hline $\mathrm{y} 4 \mathrm{yE}$ & nорB & nolB & NopB (NolB, SR4) ${ }^{d}$ & Secreted protein/nodulation ${ }^{c}$ & This work \\
\hline $\mathrm{y} 4 \mathrm{yF}$ & rhcJ & nolT & RhcJ & Protein secretion/nodulation ${ }^{c}$ & Meinhardt; Krishnan \\
\hline y4yG & nolU & $\ldots$ & NolU & Cultivar-specific nodulation ${ }^{\mathrm{c}}$ & Meinhardt \\
\hline $\mathrm{y} 4 \mathrm{yH}$ & $\ldots$ & nolV & NolV & Cultivar-specific nodulation ${ }^{\mathrm{c}}$ & Meinhardt \\
\hline y4yI & $\operatorname{rhcN}$ & $\ldots$ & $\mathrm{RhcN}$ & Protein secretion/nodulation ${ }^{\mathrm{c}}$ & Meinhardt; Krishnan \\
\hline $\mathrm{y} 4 \mathrm{yJ}$ & $\ldots$ & $\ldots$ & & Unknown & Viprey; Krishnan \\
\hline y4yK & $\operatorname{rhc} Q$ & $\ldots$ & RhcQ & Protein secretion & Viprey \\
\hline y4yL & $\operatorname{rhcR}$ & $\ldots$ & RhcR & Protein secretion & Viprey \\
\hline y4yM & rhcS & $\ldots$ & RhcS & Protein secretion & Viprey \\
\hline $\mathrm{y} 4 \mathrm{yN}$ & $\operatorname{rhcT}$ & $\ldots$ & RhcT & Protein secretion & Viprey \\
\hline $\mathrm{y} 4 \mathrm{yO}$ & $\operatorname{rhc} U$ & $\ldots$ & RhcU & Protein secretion & Viprey \\
\hline $\mathrm{y} 4 \mathrm{yP}$ & nорP & $\ldots$ & NopP (SR3, Nop34) ${ }^{\mathrm{d}}$ & Secreted protein & Ausmees et al. 2004 \\
\hline$* \mathrm{e}$ & порА & $\ldots$ & NopA (SR5, Nop7) & Secreted protein & Krishnan 93; Marie \\
\hline y4yQ & $\ldots$ & $\ldots$ & $\ldots$ & Unknown & Viprey; Krishnan \\
\hline y4yR & $r h c V$ & $\ldots$ & RhcV & Protein secretion & Viprey \\
\hline
\end{tabular}

${ }^{\text {a }}$ In both USDA257 and NGR234, the TTSS is located in the sym plasmid.

${ }^{\mathrm{b}}$ Krishnan = Krishnan et al. 2003; Marie = Marie et al. 2003; Viprey = Viprey et al. 1998; Bartsev = Bartsev et al. 2004; Jiang = Jiang and Krishnan 2000; Krishnan 93 = Krishnan and Pueppke 1993; Meinhardt = Meinhardt et al. 1993; Krishnan 02 = Krishnan 2002

${ }^{c}$ Could either positively or negatively affect the nodulation process in a host-dependent manner.

d Old protein nomenclature.

${ }^{\mathrm{e}}$ Start codon of nopA is located $322 \mathrm{bp}$ upstream of y4yQ and was not annotated in the earlier DNA sequence submissions.

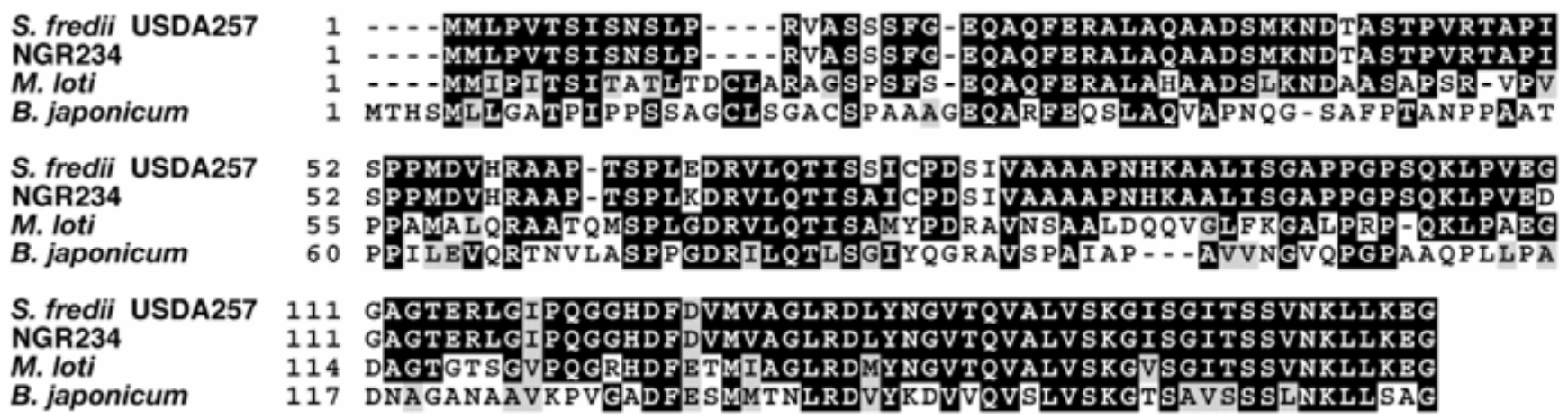

Fig. 2. Multiple alignment of the amino acid sequence of NopB from different symbiotic rhizobia. The amino acid sequence of NopB from USDA257, NGR234, Mesorhizobium loti MAFF303099, and Bradyrhizobium japonicum 110spc4 appear in Swiss-Prot database under accession numbers P33208, P55713, Q989P6, and Q89TP9, respectively. NopB sequences were aligned with the help of Clustal W and Boxshade programs. Dashes indicate gaps to facilitate best alignment. Black and gray boxes represent identical and similar amino acids, respectively. 
teins of $44,40,37,34$, and $30 \mathrm{kDa}$, which is in agreement with the sizes expected for the NopB-GFP hybrids (Fig. 6). The antibodies also reacted against the native $18-\mathrm{kDa}$ NopB. Interestingly, the accumulation of the native NopB was reduced in strains that carried the nopB-gfp reporter (Fig. 6). Constructs that retained a significant amount of $n o p B$ coding region showed greater reduction in the accumulation of the native 18-

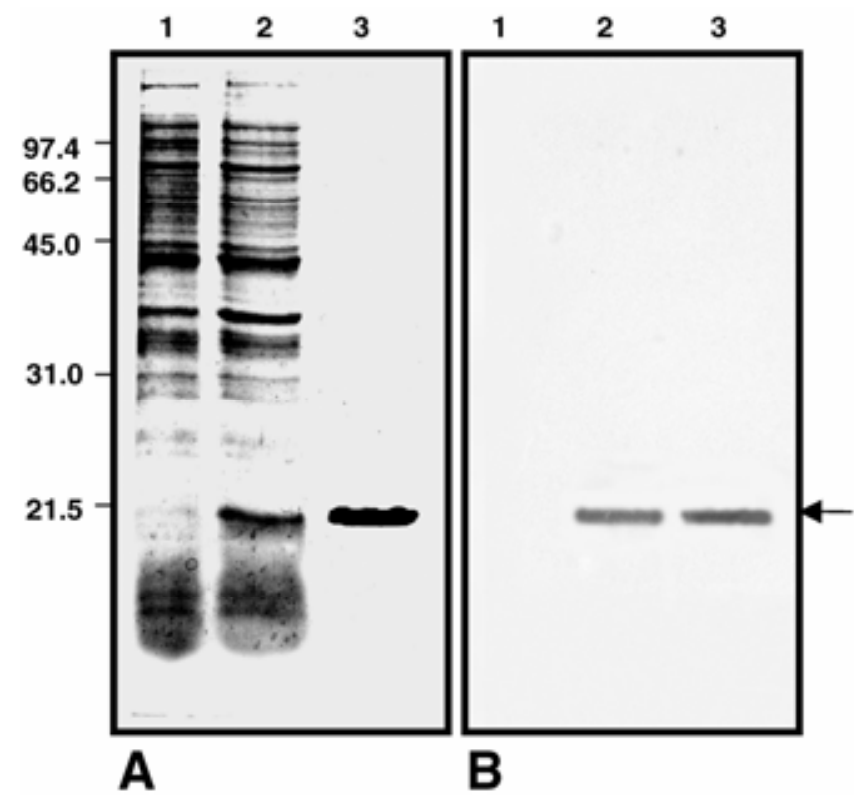

Fig. 3. Expression and purification of NopB from Escherichia coli. The coding region of NopB was cloned in an expression vector $\mathrm{pET} 28 \mathrm{a}(+)$ and introduced into E. coli BL21 (DE3). Protein expression was induced by the addition of $0.1 \mathrm{mM}$ isopropyl- $\beta$-D-thiogalactoside (IPTG) when the optical density of the culture at $600 \mathrm{~nm}$ was 0.5 . The cells were harvested $1 \mathrm{~h}$ after induction and the recombinant protein was purified on an $\mathrm{Ni}$ affinity column. A, Coomassie-stained gel and $\mathbf{B}$, Western blot. Lane 1, total proteins from cells grown in the absence of IPTG; lane 2, total proteins from cells grown in presence of IPTG; lane 3, purified NopB. The blot was probed with antibodies raised against NopB. The sizes of the molecular weight markers in kilodaltons are indicated.
kDa NopB (Fig. 6). This indicates that secretion into the extracellular media may be compromised in these strains. However, immunoblot analysis using proteins isolated from the cell pellets revealed no differences in the accumulation of the native $18-\mathrm{kDa}$ NopB (data not shown). Antibodies raised against GFP also reacted against 44-, 40-, 37-, 34-, and 30-kDa NopBGFP hybrid proteins (Fig. 6). USDA257 carrying a construct that retained only the first two $\mathrm{N}$-terminal amino acids or a construct that had the first $33 \mathrm{~N}$-terminal amino acids removed was unable to secrete the hybrid protein into the extracellular medium (Fig. 6).

\section{A nonpolar nopB deletion mutant does not produce pili.}

We have demonstrated earlier that flavonoids released by soybean roots induce USDA257 to produce pilus-like surface appendages (Krishnan et al. 2003). To determine if the nonpolar $n o p B$ deletion mutant was affected in its ability to produce surface appendages, we isolated these structures from both flavonoid-induced and noninduced wild-type and mutant cultures. The surface appendages were stained with phosphotungstic acid and viewed with electron transmission electron microscopy (Fig. 7). Preparations from the noninduced, wild-type cultures contained primarily flagella which were $10 \mathrm{~nm}$ in diameter (Fig. 7A). The addition of genistein to the culture of USDA257 resulted in the production of pili (Fig. 7B). Although flagella could be detected in this preparation, the pili were much more abundant. Noninduced cultures of nonpolar $n o p B$ deletion mutant produced flagella similar to the wild type (Fig. 7C). However, the pili were absent in the samples obtained from the flavonoid-induced nopB mutant cultures (Fig. 7D).

\section{NopB co-purifies with pili.}

To examine whether NopB was associated with surface appendages elaborated by USDA257, we purified these structures by ultracentrifugation. SDS-PAGE analysis of the surface appendages revealed two abundant flagellin proteins of 34 and $36 \mathrm{kDa}$ from the nonpolar nopB deletion mutant-induced cultures (Fig. 8A). The surface appendage preparation from the wild-type, flavonoid-induced cultures revealed the presence of

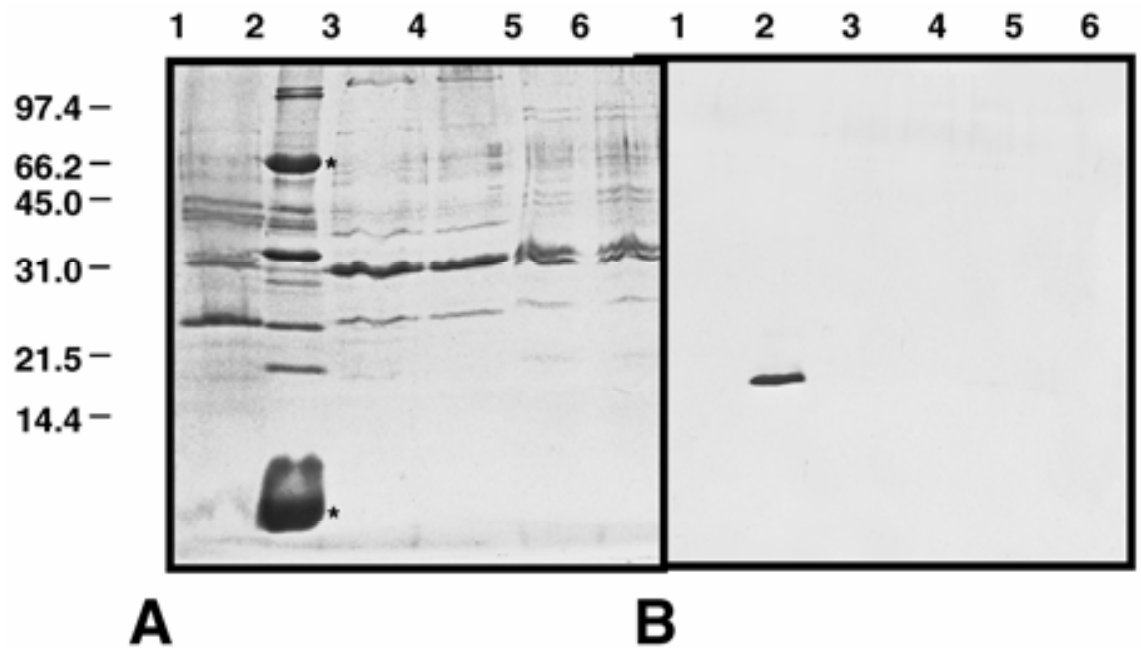

Fig. 4. Detection of NopB in extracellular proteins of USDA257. A, Extracellular protein profile. Extracellular proteins from genistein-induced and noninduced cultures of USDA257 wild-type, USDA257 $\mathrm{rhh} c \mathrm{~N}$, and USDA257 $\Delta$ nopB mutants were resolved by $15 \%$ sodium dodecyl sulfate-polyacrylamide gel electrophoresis. The separated proteins were visualized by staining with Coomassie blue. B, Immunological detection of NopB. Proteins shown in panel A were transferred to a nitrocellulose membrane and probed with NopB-specific antibodies. Proteins reacting with NopB antibodies were detected by the horseradish peroxidase color development procedure. Lane 1, USDA257 noninduced; lane 2, USDA257 genistein-induced; lane 3, USDA257 2 rhcN mutant

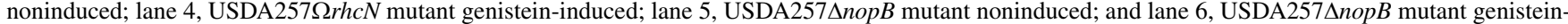
induced. Note that NopB is present only in the genistein-induced cultures of Sinorhizobium fredii USDA257. The sizes of the molecular weight markers in kilodaltons are indicated. The positions of NopX $(64 \mathrm{kDa})$ and NopA $(7 \mathrm{kDa})$ are indicated by asterisks (panel A). 


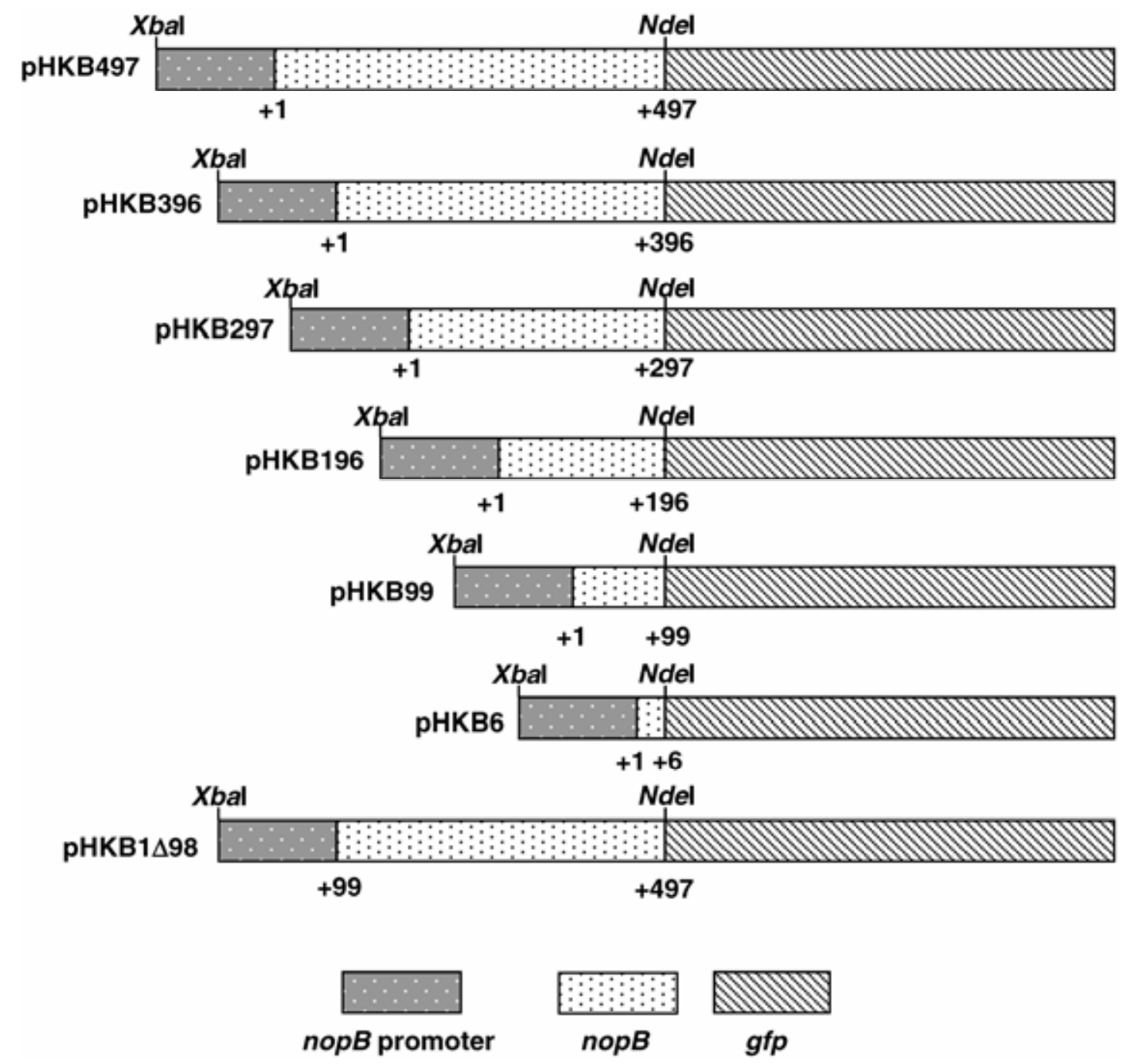

Fig. 5. Schematic representation of hybrid proteins consisting of NopB, or their truncated derivatives fused to green fluorescent protein. nopB promoter was used to express the translational reporter fusions in USDA257. Numbers represent the respective nucleotide position of nopB. Number 1 represents the start of the coding region.

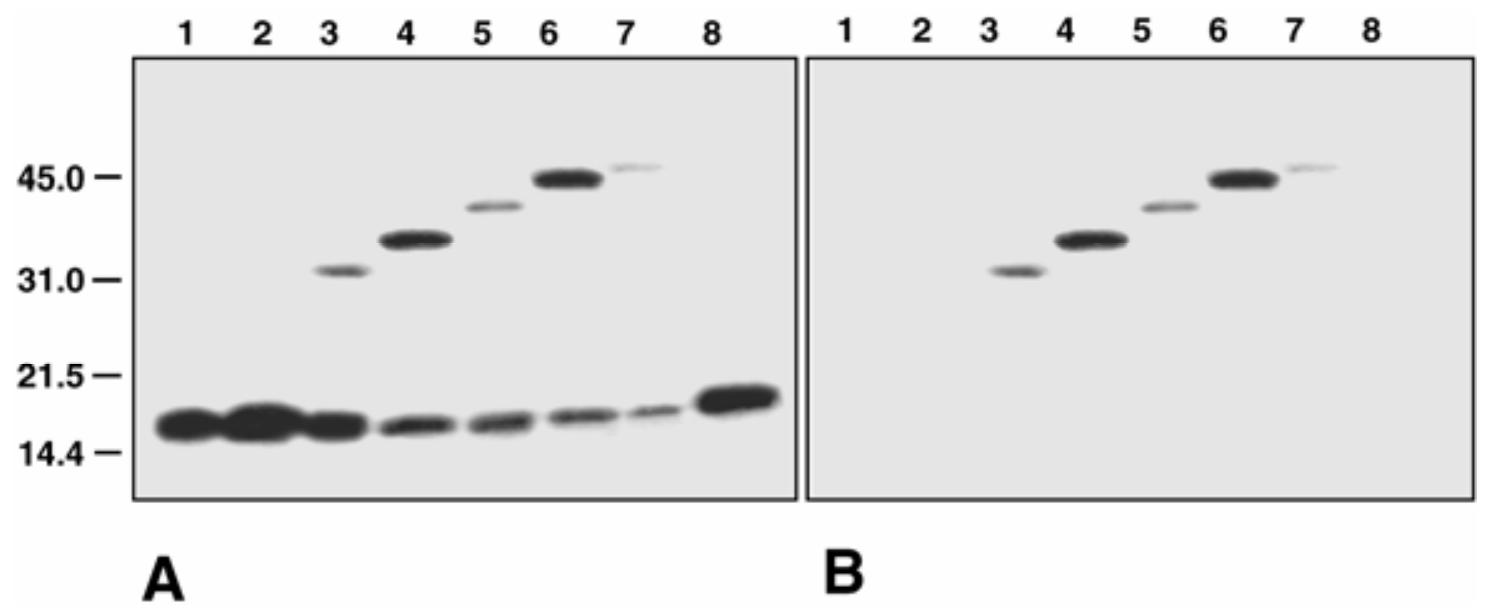

Fig. 6. Immunoblot analysis of NopB:green fluorescent protein (GFP) secretion by USDA257. Extracellular proteins from USDA257 carrying NopB and its truncated derivatives fused to GFP were separated by sodium dodecyl sulfate-polyacrylamide gel electrophoresis and subjected to immunoblot analysis. The immunoreactive polypeptides were visualized by chemiluminescent detection method. Lane 1, USDA257 (pHKB1 $\triangle 98$ ); lane 2, USDA257 (pHKB6); lane 3 , USDA257 (pHKB99); lane 4, USDA257 (pHKB196); lane 5, USDA257 (pHKB297); lane 6, USDA257 (pHKB396); lane 7, USDA257 (pHKB497); and lane 8, USDA257. A, Probed with antibodies against NopB and B, probed with GFP antiserum. The sizes of the molecular weight markers in kilodaltons are indicated. 
several Nops, including NopB (Fig. 8A). These proteins were absent from the surface appendage preparation obtained from the nopB mutant (Fig. 8A, lane 1). Western blot analysis using the recombinant NopB antibodies revealed the presence of NopB only in the pili preparations obtained from the flavonoid-induced, wild-type cultures (Fig. 8B).

\section{The nopB mutant has altered symbiotic properties.}

The ability of the USDA257 nonpolar nopB deletion mutant to nodulate soybean, cowpea (Vigna unguiculata), and siratro (Macroptilium atropurpureum), three common host plants of USDA257, was examined. The mutation appears to affect the nodulation phenotype in a host-dependent manner (Fig. 9). As documented earlier (Heron and Pueppke 1984), USDA257 was unable to nodulate the soybean cv. McCall, merely producing bumps on the taproots. The nonpolar nopB deletion mutant, however, produced nitrogenfixing nodules on McCall. Interestingly, the nop $B$ mutant, compared with the wild type, revealed reduced nodulation on soybean cv. Peking and Macroptilium spp. (Fig. 9). When compared by analysis of variance, the reduction in the number of nodules was found to be statistically significant at $P=$
0.05 . USDA257 and the nopB mutant produced an equal number of nodules on V. unguiculata (Fig. 9).

\section{DISCUSSION}

Bacterial pathogens (Galan and Collmer 1999), and some nonpathogenic bacteria (Preston et al. 2001), possess a cluster of conserved genes that encode the TTSS. In pathogens, TTSS is instrumental in synthesis and translocation of effector molecules in a contact-dependent manner into the host organism. The TTSS of Pseudomonas syringae pv. tomato serves as a model for this type of pathogenic system. The hypersensitive reaction and pathogenicity ( $h r p$ ) genes encode components of TTSS in P. syringae. Mutations in the structural components of TTSS cause negation of pathogenicity of $P$. syringae, presumably due to inability of mutants to deliver these proteins into the cytoplasm of host cells. In contrast to the plant and animal pathogens, proteins secreted by the TTSS of symbiotic bacteria are involved in regulating nodulation of legumes in a host-specific manner. NGR234 TTSS mutants NGR $\Omega r h c \mathrm{~N}$ and NGR $\Omega y 4 x I$ exhibit increased nodulation on Pachyrhizus tuberosus and decreased nodulation on Tephrosia vogelii (Viprey et
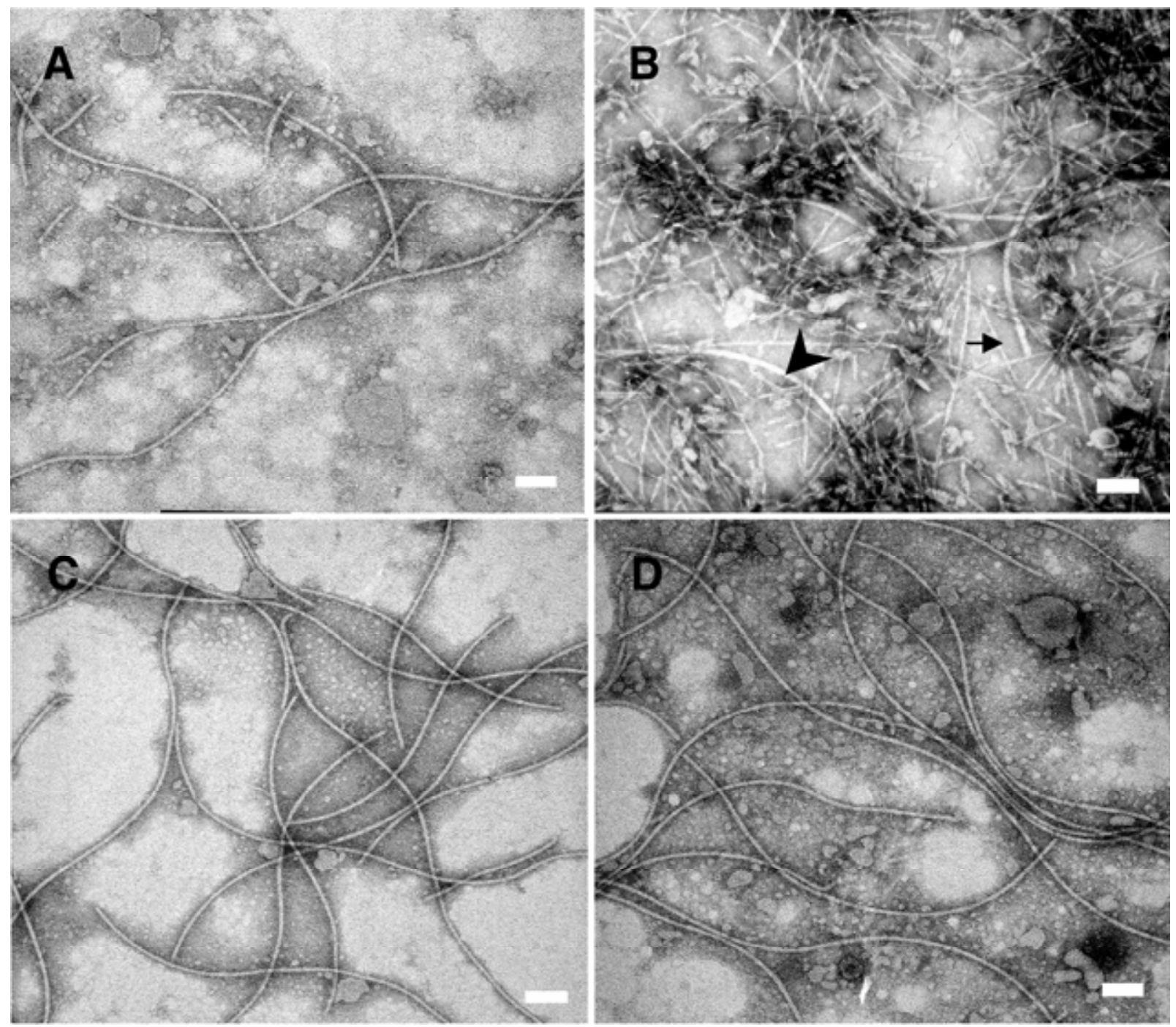

Fig. 7. Electron micrographs of surface appendages of USDA257 and USDA257 $n$ nopB mutant. Cells were grown in yeast extract mannitol broth in the presence or absence of $1 \mu \mathrm{M}$ genistein. Surface appendages were purified from the culture supernatants by ultracentrifugation and negatively stained with $1 \%$ phosphotungstic acid. A and B, Surface appendage preparations from noninduced and induced USDA257 cultures, respectively. Noninduced cultures elaborate flagella 10 to $11 \mathrm{~nm}$ in diameter, whereas the genistein-induced cultures of USDA257 elaborate, in addition to the flagella (arrowhead), large amounts of pili (arrow). C and D, Surface appendages from noninduced and induced USDA257 nnopB mutant, respectively. Note that pili are absent in the genistein-induced cultures (panel D). Scale bars represent $50 \mathrm{~nm}$. 
al. 1998). Earlier, we have shown that the USDA257 nopX and $n o p B$ mutants have the acquired ability to nodulate McCall soybean (Meinhardt et al. 1993). In addition, the inability of USDA257 to secrete NopB and other TTSS-dependent extracellular proteins has diminished its capacity to nodulate soybean cv. Peking and M. atropurpureum. Varied responses of legume hosts to the TTSS-secreted proteins demonstrate a role for these extracellular proteins in regulating nodulation in a host-specific manner.

Response of host plants to bacterial effector proteins depends upon whether the plant is resistant or susceptible to the invasive pathogen. In susceptible hosts, effector proteins elicit disease symptoms; whereas, in resistant hosts, the protein induces the hypersensitive response. Similarly, the TTSSsecreted proteins of symbiotic bacteria may elicit different responses in their legume hosts. In a specific host, the TTSSsecreted proteins may trigger plant defense responses, exerting a negative influence on nodulation. In contrast, these bacterial proteins with respect to another host may negate or avoid the plant defense response, having a positive effect on nodulation. The results from this study and from those reported earlier (Krause et al. 2002; Krishnan et al. 2003; Marie et al. 2003; Viprey et al. 1998) demonstrate that TTSS-secreted proteins can influence nodulation either positively or negatively in a host-dependent manner.

An important characteristic of the TTSS in pathogenic bacteria is the formation of supramolecular structures, pili, or needle complexes associated with the cell surface (Galan and Collmer 1999). Plant-pathogenic bacteria are characterized by the production of Hrp pili. These surface appendages are essential components of the TTSS and may function as conduits for the delivery of effector proteins into the host cells. The actual mechanism of delivery is yet not known, but there is evidence that Pseudomonas syringae pv. tomato produces functional pili that cross the plant cell wall of Arabidopsis thaliana (Hu et al. 2001). SDS-PAGE analysis of the surface appendages of $P$. syringae revealed three major proteins of 50,36 , and $10 \mathrm{kDa}$ (Roine et al. 1997). The 36-kDa protein was identified as flagellin and the $10-\mathrm{kDa}$ protein as HrpA, which is a major component of the Hrp pilus (Roine et al. 1997). Appearance of surface appendages has been noted on USDA257 and shown to be NodD1 and flavonoid dependent (Krishnan et al. 2003). These surface appendages resemble the Hrp pili of $P$. syringae strain DC3000 (Jin and He 2001). Analysis of USDA257 pili by SDS-PAGE revealed that 7-kDa NopA was the most abundant component and may be involved in the pili formation (Marie et al. 2003). However, amino acid sequence comparison of HrpA and NopA does not reveal significant homology. This observation is consistent with the fact that the genes encoding the pilin subunits are not conserved between TTSS-containing bacteria (He 1998).

The signals necessary for the secretion of type III Yop proteins have been studied intensively (Anderson and Schneewind 1997; Lloyd et al. 2002; Michiels and Cornelis 1991; Ramamurthi and Schneewind 2002; Sory and Cornelis 1994). Fusing the ORFs of Yop genes to reporters, such as alkaline phosphatase, $\beta$-galactosidase, adenylate cyclase, or neomycin phosphotransferase, translational hybrids were created to determine if the Yops were secreted by type III machinery. Based on data from these studies, it was concluded that the first 15 amino acids serve as the signal peptide for TTSS secretion (Lloyd et al. 2001; Schesser et al. 1996; Sory et al. 1995). Studies have shown that the $5^{\prime}$ end of Yop mRNA also can serve as a type III secretion signal (Anderson and Schneewind 1997). Similarly, a potential mRNA secretion signal has been identified in the TTSS-mediated secretion of AvrBs2 by the plant pathogen Xanthomonas campestris (Mudgett et al. 2000). In the current study, we have determined that first $33 \mathrm{~N}$-terminal amino acid sequences are necessary and sufficient for the secretion of NopB-GFP reporter. This observation indicates that the N-terminal amino acid sequences of type III secreted proteins of both symbiotic bacteria and plant and animal pathogens share unique features that target them for secretion.

\section{MATERIALS AND METHODS}

Microbiological and molecular techniques.

The bacterial strains and plasmids used in this study are listed in Table 2. Rhizobia were grown on a reciprocal shaker at $30^{\circ} \mathrm{C}$ in yeast extract mannitol medium (Vincent 1970) and E. coli was cultured in Luria-Bertani broth at $37^{\circ} \mathrm{C}$ (Sambrook et al. 1989). When appropriate, antibiotics were added at the following concentrations: tetracycline, $10 \mu \mathrm{g} / \mathrm{ml}$; kanamycin, $50 \mu \mathrm{g} / \mathrm{ml}$; ampicillin, $100 \mu \mathrm{g} / \mathrm{ml}$; spectinomycin, $50 \mu \mathrm{g} / \mathrm{ml}$; and gentamicin, $10 \mu \mathrm{g} / \mathrm{ml}$. Recombinant DNA manipulations were done according to standard protocols (Sambrook et al. 1989).

\section{Isolation of extracellular proteins.}

Bacterial cells were induced with $1 \mu \mathrm{M}$ genistein using starter cultures as inoculum (Krishnan and Pueppke 1993) and grown for $48 \mathrm{~h}$ at $30^{\circ} \mathrm{C}$. After removal of cells by centrifugation $(12,000 \times g, 30 \mathrm{~min})$, proteins in the supernatant were ammonium sulfate $(70 \%$ saturation) precipitated. Proteins were recovered by centrifugation $\left(8,000 \times g, 4^{\circ} \mathrm{C}, 30 \mathrm{~min}\right)$, resuspended in $300 \mu \mathrm{l}$ of $50 \mathrm{mM}$ Tris- $\mathrm{HCl}(\mathrm{pH} \mathrm{7.5)}$, desalted using Microcon YM-10 centrifugal filter units (Millipore, Bedford, MA, U.S.A.), and suspended in a final volume of $100 \mu \mathrm{l}$ of SDS sample buffer.

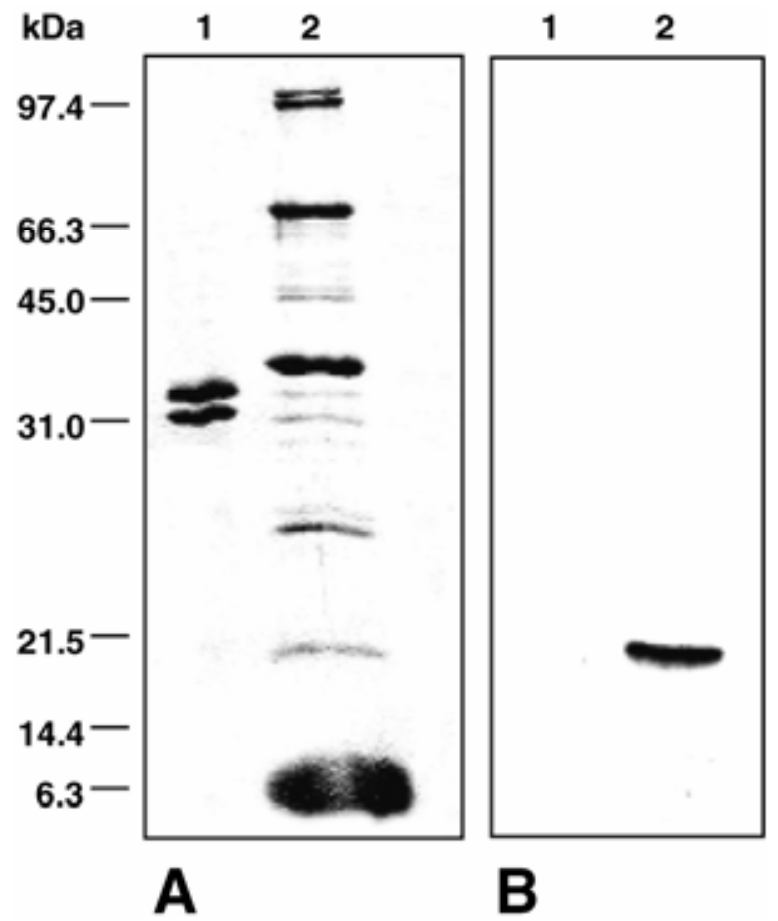

Fig. 8. NopB is associated with surface appendages of USDA257. Proteins associated with surface appendages were isolated by ultracentifugation as described in the Materials and Methods section. The proteins were resolved on $15 \%$ sodium dodecyl sulfate-polyacrylamide gel electrophoresis and $\mathbf{A}$, visualized by staining with Coomassie blue or $\mathbf{B}$, electrophoretically transferred to a nitrocellulose membrane and probed with NolB-specific antibodies. Proteins reacting with NolB antibodies were detected by the horseradish peroxidase color development procedure. Lane 1, genistein-induced USDA257 $\triangle$ прв $B$ mutant. Lane 2, genistein-induced, wild-type USDA257. The sizes of the molecular weight markers in kilodaltons are indicated. 
Purification and analysis of bacterial surface appendages.

Surface appendages of genistein-induced USDA257 were isolated by ultracentrifugation as described earlier (Krishnan et al. 2003) and resuspended in appropriate buffers for assessment by transmission electron microscopy (TEM) or separation by gel electrophoresis. For TEM examination, a drop of the purified surface appendage suspension was applied to a carbon-coated copper grid and stained with $1 \%$ phosphotungstic acid ( $\mathrm{pH}$ 6.5). The grids were examined by electron microscope at $100 \mathrm{kV}$. Proteins associated with the surface appendages were identified by resuspending the pellet from the ultracentrifugation step directly in $100 \mu \mathrm{l}$ of SDS sample buffer (2\% SDS, $10 \%$ glycerol, 0.125 M Tris-HCL, $\mathrm{pH} 6.8,0.1 \%$ bromophenol blue, and $5 \% \beta$-mercaptoethanol). Samples were boiled for $3 \mathrm{~min}$ and aliquots were resolved by $15 \%$ SDS-PAGE (Laemmli 1970). Proteins were visualized by staining with Coomassie Brilliant Blue (SigmaAldrich, St. Louis). Western blot analysis was performed as described (Burnett 1981). NopB antibodies were used at a final dilution of 1:10,000. Immunoreactive polypeptides were identified following the horseradish peroxidase color devel- opment procedure provided by the manufacturer (Bio-Rad, Hercules, CA, U.S.A.).

Amino-terminal sequence analysis.

Flavonoid-induced extracellular proteins from $S$. fredii USDA257 were resolved by SDS-PAGE and transferred to a polyvinylidene fluoride (PVDF) membrane. After transfer, the PVDF membrane was stained briefly with Ponceau S (SigmaAldrich), and the membrane containing the immobilized $18-\mathrm{kDa}$ protein was excised. The amino-terminal sequence was determined with an automated gas liquid solid-phase protein sequenator at the Protein Core Facility of the University of Missouri.

\section{Preparation of recombinant NopB.}

To express NopB in $E$. coli, the entire coding region of the $n o p B$ was amplified by polymerase chain reaction (PCR). The PCR-generated fragment was cloned into pET28a(+) (Novagen, Madison, WI, U.S.A.) vector as NdeI/BamHI fragment, resulting in a $\mathrm{C}$-terminal $\mathrm{His}_{6}$ tag. This expression vector was then introduced in E. coli cells BL21 (DE3) (Novagen). The His $6^{-}$ tagged NopB protein expression was initiated by induction

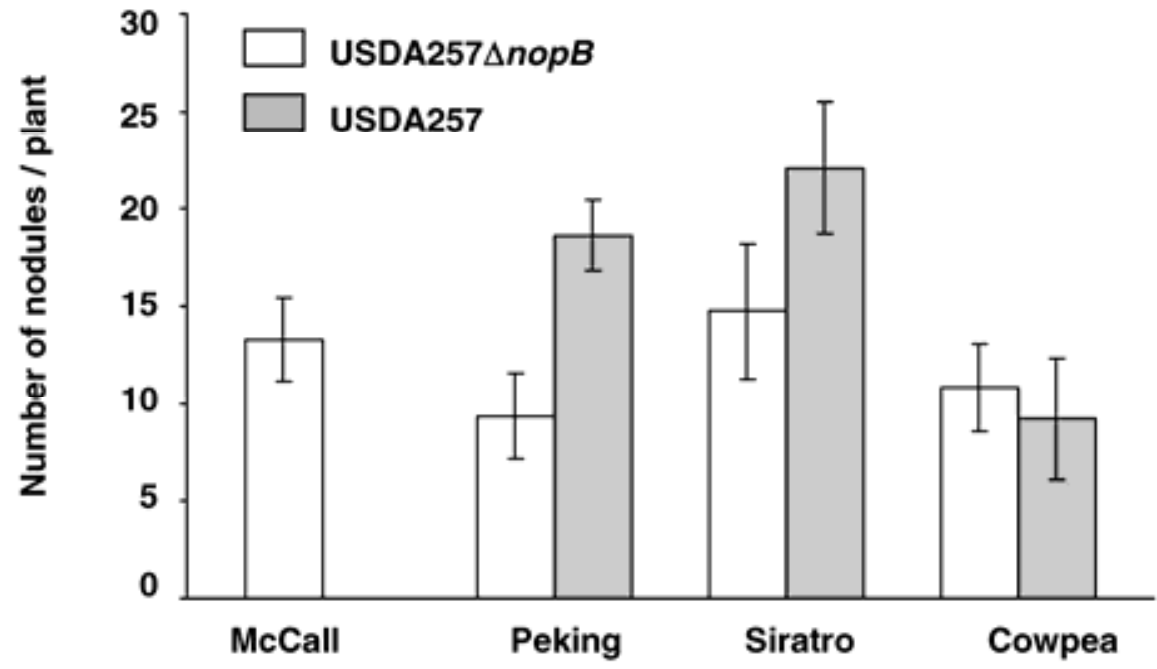

Fig. 9. Symbiotic phenotype of the USDA257 nnopB mutant. Seedlings of Glycine max cvs. McCall and Peking, Macroptilium atropurpureum (siratro), and Vigna unguiculata (cowpea) were inoculated with either USDA257 or USDA257DnopB mutant and the number of nodules formed 26 days after inoculation was counted. Average number of nodules and standard errors of the means are shown. Results are from three independent experiments.

Table 2. Bacterial strains and plasmids used in this study

\begin{tabular}{|c|c|c|}
\hline Strains/plasmids & Relevant characteristics $^{\mathbf{a}}$ & Source or reference \\
\hline \multicolumn{3}{|l|}{ Rhizobium strains } \\
\hline Sinorhizobium fredii USDA257 & Broad-host-range, $\mathrm{Nod}^{+}$on soybean & Heron and Pueppke 1984 \\
\hline 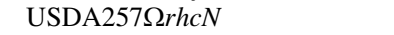 & USDA257 derivative containing an $\Omega$ insertion in $r h c N, \mathrm{Sp}^{\mathrm{r}}$ & Krishnan et al. 2003 \\
\hline USDA257 & USDA257 derivative in which $n \circ p B$ has been replaced with $n p t I I \mathrm{Kn}^{\mathrm{R}}$ & This study \\
\hline \multicolumn{3}{|l|}{ Escherichia coli } \\
\hline DH5 $\alpha$ & 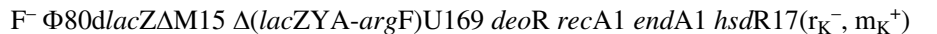 & Life Technologies ${ }^{b}$ \\
\hline BL21(DE3) & $\mathrm{F}^{-}$ompT hsdS $S_{\mathrm{B}}\left(r_{\mathrm{B}}{ }^{-}, m_{\mathrm{B}}{ }^{-}\right)$gal dcm $(\mathrm{DE} 3)$ & Novagen, Madison, WI \\
\hline \multicolumn{3}{|c|}{ - } \\
\hline pGEM-T Easy & Polymerase chain reaction cloning vector $\mathrm{Ap}^{\mathrm{r}}$ & Promega, Madison, WI \\
\hline pGEM-7Zf(+) & Cloning vector $\mathrm{Ap}^{\mathrm{r}}$ & Promega, Madison, WI \\
\hline pT7Blue & Cloning vector $\mathrm{Ap}^{\mathrm{r}}$ & Novagen, Madison, WI \\
\hline pET-28a(+) & Expression vector $\mathrm{Km}^{\mathrm{r}}$ & Novagen, Madison, WI \\
\hline pRfDH412 & $\begin{array}{l}\text { 8.0-kb EcoRI fragment containing the nolXWBTUV genomic fragment of } \\
\text { S. fredii USDA257 in pGEM-7Zf(+). }\end{array}$ & Meinhardt et al. 1993 \\
\hline pBSKSII & Cloning vector, $\mathrm{Amp}^{\mathrm{r}}$ & Promega \\
\hline pRK2013 & incPl helper plasmid, $\mathrm{Km}^{\mathrm{r}}$ & Figurski and Helinski 1979 \\
\hline pCPP2988 & $\begin{array}{l}\text { pBluescript II KS vector carrying } 1.5-\mathrm{kb} \text { HindIII SalI fragment from pRZ102 with } \\
\text { nptII lacking terminator }\end{array}$ & Alfano et al. 1996 \\
\hline pJLB406 & $\begin{array}{l}\text { 5.1-kb insert with } \triangle \text { nopB:: nptII between the flanking regions of } n o p B \text { cloned in } \\
\text { pJQ200mp18 } \mathrm{Km}^{\mathrm{r}}, \mathrm{Gm}^{\mathrm{r}}\end{array}$ & This study \\
\hline
\end{tabular}

\footnotetext{
a Ap, ampicillin; Km, kanamycin; Gm, gentamicin; Sp, spectinomycin.
}

${ }^{\mathrm{b}}$ Life Technologies, Gibco BRL, Grand Island, NY. 
with $0.1 \mathrm{mM}$ IPTG. The recombinant NopB which was purified by nickel-affinity column chromatography (Qiagen, Valencia, CA, U.S.A.) was desalted and concentrated with a microcon13 (Millipore). Further purification of NopB was achieved by preparative PAGE. Antibodies against the purified recombinant NopB were raised in a New Zealand white female rabbit essentially as described earlier (Krishnan and Okita 1986).

\section{Construction of nonpolar $\Delta$ nopB::nptII mutant.}

DNA regions upstream $(1.6 \mathrm{~kb})$ and downstream $(2.0 \mathrm{~kb})$ from the start and stop codon of nopB were amplified by PCR using pRF447 DNA as a template. Primers for the upstream region 5'-GTTCGGGATCCTGTAGCAATGCCTCGATTGCC GC-3' and 5'-GCATCCCGGGAAGGACTCGATTACTTAAC TC-3' included BamHI and SmaI restriction sites, while those for downstream region 5'-GAAGGCCCCGGGGCGGCGAT GTTCGGCTCAGCCC-3' and 5'-CGTAGGTACCGTTTCAATT CGAACCTTGGCCGC-3' contained SmaI and KpnI sites to facilitate cloning. An nptII cassette without the rho-independent transcriptional terminator was excised from pCPP2988 (Alfano et al. 1996) and inserted between PCR-amplified sequences upstream and downstream from nopB. The resulting DNA fragment, in which $n o p B$ was replaced with $n p t I \mathrm{I}$, was subcloned into the SmaI site of vector pJQ200mp18, resulting in pJLB406. This construct was mobilized into $S$. fredii USDA257 by triparental mating with helper plasmid pRK2013 (Figurski and Helinski 1979). Double recombination was selected by plating the bacteria on minimal medium plates containing 5\% (wt/vol) sucrose. Mutants were confirmed by Southern blot hybridizations.

\section{Construction of NopB-GFP reporters.}

The promoter and the coding region of $n o p B$ was amplified from the genomic DNA by PCR with primers NopBF, 5'-A ACTCTAGAACACTGATTTTCAGGTTGTTGCCG-3', and NopB+497, 5'-GGTCATATGCCCTTCCTTTAATAGTTTGTT TAC-3', yielding a 642-bp fragment with 5' XbaI and 3' NdeI restriction sites. This fragment was cloned into pBluescript II SK (+), yielding pHBK497. Deletions containing progressively smaller segments of the N-terminal of NopB were generated with the use of common $5^{\prime}$ primer (NopBF) in combination with primers NolB+396 (5'-GGTCATATGACCGGCAACCATCAC GTCAAAATC-3'), NopB+297 (5'-GGTCATATGCGGAGCGC CGCTTATAAGGGCCG-3'), NopB+196 (5'-GGTCATATGCA GCGGGCTCGTTGGCGCCGCG-3'), NopB+99 (5'-GGTCAT ATGCGCCTGTGCCAGAGCACGCTC-3'), NopB+6 (5'-GGT CATATGCATCATGAGAAGGACTCGATTAC-3'), and NopB+1 (5'-GGTCATATGGCTGATTCGATGAAAAACGATACTG-3').

The resulting PCR products were cloned into the $\mathrm{Xba \textrm {I }}$ and $\mathrm{NdeI}$ site of into pBluescript II SK (+) (Stratagene, La Jolla, CA, U.S.A.), resulting in pHKB396, pHKB297, pHKB196, pHKB99, pHKB6, and pHKB1 199 , respectively (Fig. 6). pHK10 was constructed through ligation of the coding region of GFP into pET28a vector backbone liberated with $\mathrm{XbaI}$ and EcoRV restriction sites. The N-terminus of the GFP contains an NdeI restriction site to facilitate in-frame fusion of the NopB deletions. The final constructs (nopB deletions $+g f p$ ) were ligated into the $K p n \mathrm{I}$ and $X b a \mathrm{I}$ restriction sites of pRK415, a broad-host-range mobilize vector. These constructs were mobilized into $S$. fredii USDA257 by triparental mating with helper plasmid pRK2013 (Figurski and Helinski 1979).

\section{Nodulation tests.}

Surface-sterilized seed were germinated on $1 \%$ water-agar plates at $30^{\circ} \mathrm{C}$ for 2 to 3 days. The roots of the seedlings were dipped in a suspension of bacteria of known density. Inoculated seedlings were placed in vermiculite filled-Magenta jars.
Plants were placed in a growth chamber that was maintained at a constant temperature of $28^{\circ} \mathrm{C}$ with light intensity of $500 \mu \mathrm{E}$ $\mathrm{m}^{-2} \mathrm{~s}^{-1}$ under a 12-h day and night cycle. Plants were harvested 26 days after inoculation, and the nodules formed on the roots were counted.

\section{ACKNOWLEDGMENTS}

J. C. Lorio and W. S. Kim contributed equally to this work. Names are necessary to report factually on available data; however, the University of Missouri or the United States Department of Agriculture (USDA) neither guarantees nor warrants the standard of product, and the use of the name by the University of Missouri or USDA implies no approval of the product to the exclusion of others that may be suitable. We thank L. Darrah, J. Bennett, D. Emerich, J. Polacco, and W. Gassmann for critical review of this manuscript.

\section{LITERATURE CITED}

Alfano, J. R., Bauer, D. W., Milos, T. M., and Collmer, A. 1996. Analysis of the role of the Pseudomonas syringae pv. syringae HrpZ harpin in elicitation of the hypersensitive response in tobacco using functionally non-polar hrpZ deletion mutations, truncated HrpZ fragments, and hrmA mutations. Mol. Microbiol. 19:715-728.

Anderson, D. M., and Schneewind, O. 1997. A mRNA signal for the type III secretion of Yop proteins by Yersinia enterocolitica. Science 278:1140-1143.

Balatti, P. A., and Pueppke, S. G. 1990. Nodulation of soybean by transposon-mutant of Rhizobium fredii USDA257 is subject to competitive nodulation blocking by other rhizobia. Plant Physiol. 94:1276-1281.

Bartsev, A. V., Boukli, N. M., Deakin, W. J., Stachelin, C., and Broughton, W. J. 2003. Purification and phosphorylation of the effector protein NopL from Rhizobium sp. NGR234. FEBS (Fed. Eur. Biol. Soc.) Lett. 554:271-274.

Bartsev, A. V., Deakin, W. J., Boukli, N. M., McAlvin, C. B., Stacey, G., Malnoë, P., Broughton, W. J., and Stachelin, C. 2004. NopL, an effector protein of Rhizobium sp. NGR234, thwarts activation of plant defense reactions. Plant Physiol. 134:871-879.

Burnett, W. N. 1981. Western blotting: electrophoretic transfer of proteins from SDS-polyacrylamide gels to unmodified nitrocellulose and radiographic detection with antibody and radioiodinated protein-A. A. Anal. Biochem. 112:195-203.

Economou, A., Davies, A. E., Johnson, A. W. B., and Downie, J. A. 1994 The Rhizobium leguminosarum biovar viciae nodO gene can enable a node mutant of Rhizobium leguminosarum biovar trifoli to nodulate vetch. Microbiology 140:2341-2347.

Figurski, D., and Helinski, D. R. 1979. Replication of an origin-containing derivative of plasmid $\mathrm{RK}_{2}$ dependent on a plasmid function provided in trans. Proc. Natl. Acad. Sci. U.S.A. 76:1648-1652.

Galan, J. E., and Collmer, A. 1999. Type III secretion machines: bacterial devices for protein delivery into host cells. Science 284:1322-1328.

Göttfert, M., Rothlisberger, S., Kundig, C., Beck, C., Marty, R., and Henneeke, H. 2001. Potential symbiosis-specific genes uncovered by sequencing a 410-kilobase DNA region of the Bradyrhizobium japonicum chromosome. J. Bacteriol. 183:1405-1412.

He, S. Y. 1998. Type III protein secretion systems in plant and animal pathogenic bacteria. Annu. Rev. Phytopathol. 36:363-392.

Heron, D. S., Ersek, T., Krishnan, H. B., and Pueppke, S. G. 1989. Nodulation mutants of Rhizobium fredii USDA257. Mol. Plant-Microbe Interact. 2:4-10.

Heron, D. S., and Pueppke, S. G. 1984. Mode of infection, nodulation specificity, and indigenous plasmids of 11 fast-growing Rhizobium japonicum strains. J. Bacteriol. 160:1061-1066.

Hu, W., Yuan, J., Jin, Q.-L., Hart, P., and He, S. Y. 2001. Immunogold labeling of Hrp Pili of Pseudomonas syringae pv. tomato assembled in minimal medium and in planta. Mol. Plant-Microbe Interact. 14:234-241.

Jin, Q., and He, S. Y. 2001. Role of the Hrp pilus in type III protein secretion in Pseudomonas syringae. Science 294:2556-2558.

Keyser, H. H., Bohlool, B. B., Hu, T. S., and Weber, D. F. 1982. Fastgrowing rhizobia isolated from root nodules of soybean. Science 215:1631-1632.

Kovacs, L. G., Balatti, P. A., Krishnan, H. B., and Pueppke, S. G. 1995. Transcriptional organization and expression of nolXWBTUV, a locus that regulates cultivar-specific nodulation of soybean by Rhizobium fredii USDA257. Mol. Microbiol. 17:923-933.

Krause, A., Doerfel, A., and Göttfert, M. 2002. Mutational and transcriptional analysis of the type III secretion system of Bradyrhizobium japonicum. Mol. Plant-Microbe Interact. 15:1228-1235. 
Krishnan, H. B. 2002. NolX of Sinorhizobium fredii USDA257, a type IIIsecreted protein involved in host range determination, is localized in the infection threads of cowpea (Vigna unguiculata [L.] Walp.) and soybean (Glycine max [L.] Merr.) nodules. J. Bacteriol. 184:831-839.

Krishnan, H. B., Kuo, C.-I., and Pueppke, S. G. 1995. Elaboration of flavonoid-induced proteins by the nitrogen-fixing soybean symbiont Rhizobium fredii is regulated by both nodD1 and nodD2, and is dependent on the cultivar-specificity locus, nolXWBTUV. Microbiology 141:2245-2251.

Krishnan, H. B., Lorio, J., Kim, W. S., Jiang, G., Kim, K. Y., DeBoer, M., and Pueppke, S. G. 2003. Extracellular proteins involved in soybean cultivar-specific nodulation are associated with pilus-like surface appendages and exported by a type III protein secretion system in Sinorhizobium fredii USDA257. Mol. Plant-Microbe Interact. 16:617-625.

Krishnan, H. B., and Okita, T. W. 1986. Structural relationship among the rice glutelin polypeptydes. Plant Physiol. 81:748-753.

Krishnan, H. B., and Pueppke, S. G. 1993. Flavonoid inducers of nodulation genes stimulate Rhizobium fredii USDA257 to export proteins into the environment. Mol. Plant-Microbe Interact. 6:107-113.

Laemmli, U. K. 1970. Cleavage of structural proteins during the assembly of the head of bacteriophage T4. Nature (Lond.) 227:680-685.

Lee, C. A. 1997. Type III secretion systems: machines to deliver bacterial proteins into eukaryotic cells? Trends Microbiol. 5:149-156.

Lloyd, S. A., Norman, M., Rosqvist, R., and Wolf-Watz, H. 2001. Yersinia YopE is targeted for type III secretion by N-terminal, not mRNA, signals. Mol. Microbiol. 39:520-531.

Lloyd, S. A., Sjostrom, M., Andersson, S., and Wolf-Watz, H. 2002. Molecular characterization of type III secretion signals via synthetic N-terminal amino acid sequences. Mol. Microbiol. 43:51-59.

Marie, C., Broughton, W. J., and Deakin, W. J. 2001. Rhizobium Type III secretion systems: legume charmers or alarmers? Curr. Opin. Plant Biol. 4:336-342.

Marie, C., Deakin, W. J., Viprey, V., Kopcińska, J., Golinowski, W., Krishnan, H. B., Perret, X., and Broughton, W. J. 2003. Characterization of Nops, nodulation outer proteins, secreted via the type III secretion system of NGR234. Mol. Plant-Microbe Interact. 16:743-751.

Meinhardt, L. W., Krishnan, H. B., Balatti, P. A., and Pueppke, S. G. 1993. Molecular cloning and characterization of a sym plasmid locus that regulates cultivar-specific nodulation of soybean by Rhizobium fredii USAD257. Mol. Microbiol. 9:17-29.

Michiels, T., and Cornelis, G. R. 1991. Secretion of hybrid proteins by the Yersinia Yop export system. J. Bacteriol. 173:1677-1685.
Mudgett, M. B., Chesnokova, O., Dahlbeck, D., Clark, E., Rossier, O., Bonas, U., and Staskawicz, J. 2000. Molecular signals required for type III secretion and translocation of the Xanthomonas campestris AvrBs2 protein into pepper plants. Proc. Nat. Acad. Sci. U.S.A. 97:13324-13329.

Preston, G. M., Bertrand, N., and Rainey, P. B. 2001. Type III secretion in plant growth-promoting Pseudomonas fluorescens SBW25. Mol. Microbiol. 41:999-1014.

Pueppke, S. G., and Broughton, W. J. 1999. Rhizobium sp. strain NGR234 and $R$. fredii USDA257 share exceptionally broad, nested host ranges. Mol. Plant-Microbe Interact. 12:293-318.

Ramamurthi, K. S. and Schneewind, O. 2002. Yersinia enterocolitica type III secretion: mutational analysis of the yop $Q$ secretion signal. J. Bacteriol. 184:3321-3328.

Roine, E., Wei, W., Yuan, J., Nurmiaho-Lassila, N., Kalkinen, N., Romantschuk, M., and He, S. Y. 1997. Hrp pilus: An hrp-dependent bacterial surface appendage produced by Pseudomonas syringae pv. tomato DC3000. Proc. Nat. Acad. Sci. U.S.A. 94:3459-3464.

Sambrook, J., Fritsch, E. F., and Maniatis, T. 1989. Molecular Cloning: A Laboratory Manual, 2nd ed. Cold Spring Harbor Laboratory Press, Cold Spring Harbor, NY, U.S.A.

Schesser, K., Fritzh-Lindsten, E., and Wolf-Watz, H. 1996. Delineation and mutational analysis of the Yersinia pseudotuberculosis YopE domains which mediate translocation across bacterial and eukaryotic cellular membranes. J. Bacteriol. 178:7227-7233.

Sory, M.-P., Boland, A., Lambermont, I., and Cornelis, G. R. 1995. Identification of the YopE and YopH domains required for secretion and internalization into the cytosol of macrophages, using cyaA gene fusion approach. Proc. Natl. Acad. Sci. U.S.A. 92:11998-12002.

Sory, M.-P., and Cornelis, G. R. 1994. Translocation of a hybrid YopEadenylate cyclase from Yersinia enterocolitica into HeLa cells. Mol. Microbiol. 14:583-594.

Sutton, J. M., Lea, E. J., and Downie, J. A. 1994. The nodulation-signaling protein NodO from Rhizobium leguminosarum biovar viciae forms ion channels in membranes. Proc. Natl. Acad. Sci. U.S.A. 91:9990-9994.

Vincent, J. M. 1970. A Manual for the Practical Study of Root-Nodule Bacteria. Blackwell Scientific Publications, Oxford, U.K.

Viprey, V., Greco, A. D., Golinowski, W., Broughton, W. J., and Perret, X. 1998. Symbiotic implications of type III protein secretion machinery in Rhizobium. Mol. Microbiol. 28:1381-1389.

Xi, C., Schoeters, E., Vanderleyden, J., and Michiels, J. 2000. Symbiosisspecific expression of Rhizobium etli casA encoding a secreted calmodulin-related protein. Proc. Natl. Acad. Sci. U.S.A. 97:1111411119. 